\title{
A Literature Review on the Relationship between Foreign Trade
}

\section{and Economic Growth}

\author{
Huan Chen \\ School of International Business \\ Southwest University of Finance and Economics \\ NO.55, Guanghuacun Street, Qingyang District \\ Chengdu 610074, China \\ E-mail: chenhuan_369@126.com
}

\begin{abstract}
Over the past years, the relationship between foreign trade and economic growth has been the debate of economic research in academe. On this issue, economists at home and abroad used the relative data of china and got different conclusions by different methods. At first, this thesis reviews the theories of the relationship between foreign trade and economic growth, and then sum up the main arguments of modern empirical economics. Finally, the author makes a brief comment and put forward some questions that should be explored in depth in this area. It provides a broader and more comprehensive perspective to the later researchers.
\end{abstract}

Keywords: Causality test, Technology spillover, Least squares, Regression analysis

The relationship between economic growth and foreign trade was focused by many economists when foreign trades come into being. With the development of foreign trade, it has been the debate of economic research in academe because of its impact on economic growth. To some extent, the emergence of foreign trade and its development were closely related with economic growth. In a way, foreign trade indeed promotes economic growth of a country.

\section{The Review of the Theory on the Relationship}

\subsection{The Standpoint of Marx}

In accordance with the Marxist point, the relationship between the two was the relationship between exchange and production in the final analysis. Marx said: "the depth, breadth and the way of exchange are decided by the development and structure of production. ... We can see that all the elements of exchange are included in the production directly, or are decided by it." Essentially, production decides the exchange, but the exchange which is a stage of the exchange, is not merely decided by it and could react to produce under certain conditions. Sometimes, the counteractive of promoting or inhibiting is tremendous. On one hand, the expansion of production needs a growing market; on the other hand, the growing market will promote the expansion of production continuously. So, production and exchange, affect each other every seconds. This provides a very important revelation to many economists.

\subsection{The theory of western schools on the relationship}

\subsubsection{The classical school of economics}

They believed that foreign trade promoted economic growth in two ways. On the one hand, foreign trade improved the optimal distribution of resources and productivity consequentially and then stimulated the economic growth; on the other hand, one country could gain raw materials and equipments which it could not produce. Those provided the material basis for economic development. The most famous theories were exports of surplus of Adam Smith, comparative advantage of David Ricardo, the interests of the trade development of John Mueller and "trade is the engine of economic growth" of $\mathrm{D} \cdot \mathrm{H} \cdot$ Robert Morrison. All these theories interpreted the relationship to some extent but ignored that the international environment is complex and ruleless.

\subsubsection{The structure school}

The representative is Lewis, who put forward dual economy model which parted a developing economy into capitalist part (the industry sector) and non-capitalist part (the traditional agricultural sector). The capitalist sector was bound to promote the growth of the economy through absorbing and accumulating surplus labor from non-capitalist sector. If the capitalist part produced the exporting goods and the traditional part produced the importing goods, foreign trade would undoubtedly expand the market and demand of products in capitalist part and reduce the wages of labor. Then it would 
further increase the profit and accumulation of the part and promote economic growth.

\subsubsection{The effect school}

The main point of Max Corden was that he analyzed foreign trade together with macro-economic variables and especially emphasized the impact of trade on the supply of production factors and productivity. Corden recognized that a country's foreign trade would affect macroeconomic from 5 aspects: the revenue effect, the effect of capital accumulation, the substitution effect, the income distribution effect and the effect of the weighted elements. All the above effects were cumulated which meant that the impact of trade on economic growth was strengthened gradually as the development of economy.

\subsubsection{The new-growth school}

Romer, Lucas and Svensson, the representatives of this school, took technology as the core factors to promote productivity. This theory pointed out that the growth of developed countries would be attributed to the improvement of productivity. Based on this fact, the theory made a series of models to study the relationship among international trade, technological progress and economic growth. They viewed that international trade could promote economic growth through technology spillover and external stimulation. On one hand, any technology had a spill-over process. The owners of advanced technologies, whether they had intention or no intention, would gradually make other countries learn these technologies through foreign trade; on the other hand, international trade provided a broader market, more frequent exchange of information and increased competition, which forced every country to develop new technologies and products. The mutual promotion relations between international trade and technical change could ensure a long-term economic growth.

\subsubsection{The new- trade school}

The new-trade theory economist, Haierpoman Paul Krugman believed there were two ways for international trade to promote economic growth. One was the effects of economies of scale brought by trade, and the other was that international trade could promote economic growth through improving the optimal allocation of resources between materials production sector and knowledge production sector.

\section{The Main Arguments of Modern Empirical Economics}

According to the general understanding of macroeconomics, import is often recognized as a leakage of revenue which will lead to unemployment rather than economic growth. Based on this assumption, the research on relationship between economic growth and foreign trade can be taken for the study of the relationship between growth and export. That means to prove the assumptions of export-led economic growth.

\subsection{The main conclusions of western school}

\subsubsection{The conclusion of export having a single causal relationship with economic growth}

Kwan and Cotsomitis (1991), Kwan and Kwok (1995) took use of Granger causality test to study Chinese growth and foreign trade. They come to the conclusion that the output was an exogenous variable and there was a one-way causal relationship between the two. Lee added other variables, such as the trend of time, FDI and the lagging investment and so on, and concluded that export promoted economic growth by using AD.HOC model and regression analysis. But he also found the result was affected by regional differences. Behzad Yaghmaian verified the assumption of export led economic growth using time-series data and regression analysis. He found that employment and output of manufacturing sector could promote export and economic growth. In the model of classical economics, if we took the statistics of population as labor force, export marked the leading role to economic growth, but it could not be reversed.

In these empirical studies, economists used ordinary least squares (OLS) to test these cross-regional or cross-section data, and the results generally support the promotion of export to growth. But its reliability is questionable: the results from OLS only showed the relevance between foreign trade and economic growth but could not explain the existence of a causal relationship between the two.

\subsubsection{The conclusion of economic growth having a single causal relationship with export}

In this problem, Ghartey (1993) made an interesting conclusion. He analyzed respectively the economic data of United States, Japan and Taiwan through cross-section data, and found that the American GDP promoted its export, but Taiwan is quite the opposite and there was a two-way causal relationship between the two in Japan. Sharma \& Dhakal (1994) also reached the same conclusion.

\subsubsection{The conclusion of there was a two-way causal relationship between the two}

Jordan Shan and Fiona Sun (1998) took data from 1987 to 1996 as the samples and tested the two-way causal relationship between the two. They used 6 variables, which were output, export, import, investment, labor and energy consumption, to establish VAR (VAR) model. They make ADF single test and Granger causality test, and then found the result. 


\subsubsection{The conclusion of there was no causal relationship between the two}

Jung and Marshall (1985) analyzed the relationship between GDP and export of 37 developing countries in 1950-1981, and found that there was no causal relationship except Israel.

Though these empirical studies have different conclusion, they are not repellent mutually, because different researchers used different methods. Moreover, so many researches have a great inspiration to scholars at home.

\subsection{The main conclusions of domestic economic school}

Chengxiang Shen (1999) used Granger causality test and co-integration test to test the hypothesis of "Chinese export-oriented economic growth" by the data of export and GDP in china from 1977 to 1998. He found that there was a two-way causal relationship between the two, but no long-term and stable relations. The studies took only the output and export into account, but import weighed with the export - output association (Grossman, $\mathrm{G} \cdot \mathrm{M} \& \mathrm{E} \cdot$ Helpman, 1991), so the impact of import on economic growth should not be ignored. China is a developing country and its endowments elements vary considerably with developed countries. The developed countries mainly have advantage in capital and technology, but china mainly in natural resources and labor. This determines the major export products of china are agricultural products and low value-added products, and its import products are high-tech products. It can be said that the import is an important mean to break the bottleneck of economic development and promote economic growth. Meanwhile, the imported products will encourage domestic enterprises to improve product quality and production efficiency, and promote the upgrading of traditional industrial structure. As a result, the research on the relationship of import and economic growth is necessary. Jiadong Tong (1995) explored the relationship between economic growth and import, and he recognized that import at different times contributed to economy differently, but on the whole, there was a positive correlation between import and economic growth. Jingwen Li (1996) made an empirical analysis on economic growth model and pointed out that export boosted economic growth. FuWei Peng (1999) found that net exports had less relevance with economic growth. JiaQin Chen (1999) viewed that export had a great role in promoting economic growth. QuanFa Yang (1999) made Chinese data into Balassa model and found that export had a positive correlation with economy. XiaoPeng Liu (2001) started from the relevance of foreign trade and GDP growth rate and revealed that import had a strong role in the promotion of national economy by analyzing the data of china from 1980 to 1998. He also explained why Chinese export had weak correlation with economy from the angle of export structure. BoNai Fan, XiaoChi Mao, Shuang Wang (2005) studied the relationship through Granger causality model and broad difference approach, using Chinese statistics from 1952 to 2003. The result showed that Chinese GDP and export had a clear one-way causal relationship. That is to say, the export was an important factor to promote Chinese economic growth.

\section{A Simple Comment on This Issue}

3.1 Using econometric methods to explain the relationship between foreign trade and economic growth expands the vision of studying in this area, and has a profound impact on economics.

3.2 Taking foreign trade and other factors as independent variables to explore the relationship qualitatively between the two can not only explain the relationship accurately, but also make the affecting extent of independent variables on dependent variables clear. This is useful for a country to establish its foreign trade policy.

\subsection{A few problems should be explore deeper}

3.3.1 The general overlooked some important third variables, such as exports, investment and government spending.

3.3.2 The variables of many models is defined vaguely, and a possible common stochastic trend of variables has been overlooked or not been tested correctly.

3.3.3 The existing studies paid less attention to endogenous association of variables coming from the statistical process, for example, the GDP or GNP, on behalf of the economic growth, has already include the data of export.

3.3.4 The annual data was often chose by most scholars, but the quarterly data may be more suitable for measuring the causality of variables

3.3.5 The past studies over-relied on a specific study or a single method to deduct, and was lack of diversity and relativity.

\section{References}

Andy C. C \& KwanJohn A. (1991). Cotsomitis. Economic Growth and the Expanding Export Sector: China 1952-1985, International Economic Journal, 5(1): 105 - 116.

Ghartey. E. E. (1993). Casual Relationship between Exports and Economic Growth: Some Empirical Evidence in Taiwan, Japan and the US, Applied-Economics. (9): 1145-1152.

Jordan Shan \& Fiona Sun. (1998). On The Export-led Growth Hypothesis: The Econometric Evidence From China. 
Applied Economics, (30).

Jung, S. W., Marshall. Exports (1985). Growth and Causality in Developing Countries. Journal of Development Economics, (18):1-12.

Kwan A. C. C \& Cotsomitis J. A. Kwok. (1996). Economic Growth and Exogeneity: Taiwan 1953-88. The American Economist, 28(4):467-471(5).

Lee, J. W. (1993). International trade, distortion and long-run economic growth, International monetary fund staff paper, 40(2):299-328.

Shan, J. \& F. Sun. (1998b). On the Export-led Growth Hypothesis: The econometricEvidence from China. Applied Economics, 30: 1055-1065.

Shan, J. \& F. Sun. (1998a). Export-led Growth Hypothesis for Australia: An Empirical Reinvestigation. Applied Economics Letters, 5:423-428.

Sharma, S. C. \& Dhakal, D. (1994). Causal Analysis between Exports and Economic Growth in Developing Countries. Applied Economics, 26:1145- 1158.

Yaghmaian. B \& Ghorashi. R. (1995). Export Performance and Economic Development: An Empirical Analysis. The American Economist, 37-45. 